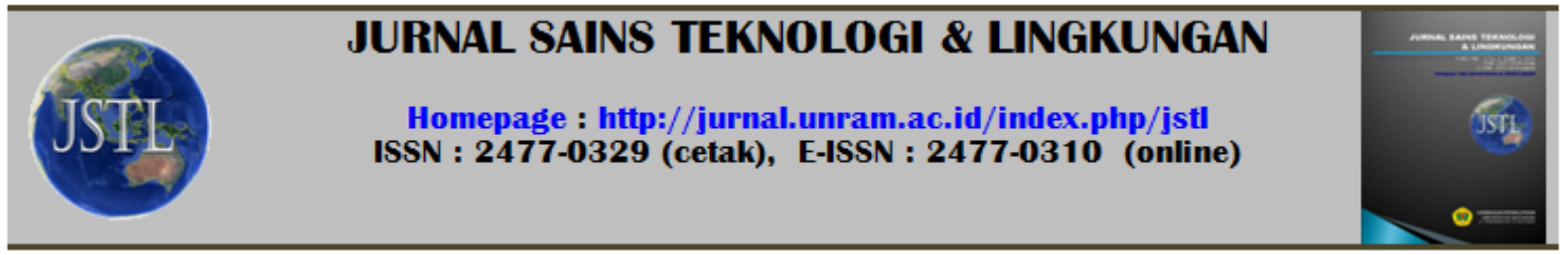

\title{
Potensi Nilai Gizi Tumbuhan Pangan Lokal Pulau Lombok Sebagai Basis Penguatan Ketahanan Pangan Nasional
}

\begin{tabular}{|c|c|}
\hline & $\begin{array}{l}\left.\left.\left.{ }^{\mathbf{1}}\right) \text { Immy Suci Rohyani, }{ }^{\mathbf{1}}\right) \text { Evy Aryanti, }{ }^{\mathbf{1}}\right) \text { Suripto } \\
\left.{ }^{1}\right) \text { Program Studi Biologi, Fakultas Matematikan dan Ilmu Pengetahuan Alam }\end{array}$ \\
\hline Kata kunci: & Abstrak \\
\hline $\begin{array}{l}\text { Nilai gizi, pangan } \\
\text { lokal, pulau Lombok }\end{array}$ & $\begin{array}{l}\text { Di pulau Lombok terdapat beberapa jenis tumbuhan lokal yang dahulunya sering dimanfaatkan } \\
\text { oleh masayarakat sebagai pangan alternatif. Pengetahuan masyarakat tentang tumbuhan pangan } \\
\text { tersebut biasanya berasal dari pengalaman hidup, pengetahuan dari turun temurun dan kearifan } \\
\text { lokal masyarakat yang perlu mendapat perhatian dalam upaya pemanfaatan yang berkelanjutan. } \\
\text { Tujuan dari penelitian ini adalah untuk mengetahui kandungan nilai gizi beberapa jenis tumbuhan } \\
\text { pangan lokal yang dikenal dan sering dimanfaatkan oleh masyarakat sebagai pangan alternatif. } \\
\text { Penelitian ini merupakan salah satu upaya pelestarian tumbuhan pangan lokal untuk penguatan } \\
\text { ketahanan pangan nasional. Penelitian ini menggunakan enam jenis tumbuhan pangan lokal yang } \\
\text { dipilih berdasarkan nilai skor dan bobot tertinggi terhadap pengetahuan serta aktifitas } \\
\text { pemanfaatan tumbuhan pangan tersebut oleh masyarakat setempat. Metode yang digunakan untuk } \\
\text { mengetahui kandungan gizi pada tumbuhan lokal tersebut diantaranya yaitu pemanasan untuk uji } \\
\text { kadar air (AOAC, 1970, Renggana } 1979 \text { ), Kjeldhal untuk uji kandungan protein, spectrometri } \\
\text { untuk uji karbohidrat, titrasi Yodium (Jacobs) untuk uji vitamin C dan AAS flame untuk uji Ca } \\
\text { (kalsium). Hasil yang diproleh bahwa buah Juwet/Jamblang (Syzygium cumini) memiliki kadar } \\
\text { air yang paling tinggi diantara keenam jenis tumbuhan lokal yang diuji, kondisi ini menyebabkan } \\
\text { buah Juwet/Jamblang (Syzygium cumini) memiliki daya simpan yang paling rendah. Kandungan } \\
\text { karbohidrat dan vitamin C tertinggi ditemukan pada buah Bune/Buni (Antidesma burnius), } \\
\text { karbohidrat yang tinggi diduga berasal dari kadar glukosa hal ini ditandai dengan rasa yang } \\
\text { sangat manis pada buah tersebut. Umbi sabrang (Coleus tuberosa) memiliki kadar protein dan } \\
\text { kalsium yang paling tinggi sehingga umbi sabrang (Coleus tuberosa) sangat baik dikonsumsi } \\
\text { sebagai cemilan maupun pengganti nasi. }\end{array}$ \\
\hline
\end{tabular}

Key words : Nutritional value, local food, the island of Lombok

\begin{abstract}
On the island of Lombok, there are several types of local plants that formerly often used by the community as an alternative food. Community awareness of the food usually comes from life experience, knowledge from generation to generation, and local wisdom. These things need attention for the sake of sustainability. The purpose of this study is to determine the content of the nutritional value of some types of local food known and frequently used by the public as an alternative food. This study is one of the local food conservation efforts for strengthening national food security. This study uses six types of local food plants selected based on the score and the highest rate of community knowledge. The level of utilization of local food by the local community is also an object of research. The method used to determine the nutrient content in the local food are heatening proses to test moisture content (AOAC, 1970; Renggana, 1979). Kjeldhal used to test protein content, spectrometry to test carbohydrates, iodine titration (Jacobs) to test vitamin C and AAS flame to test Ca (calcium). The result is that the fruit of Juwet/Jamblang (Syzygium cumini) has a highest water content among the six local food species tested. This condition causes the fruit Juwet/Jamblang (Syzygium cumini) has the lowest water storability. Carbohydrates and vitamin $C$ is of the highest content found in Bune/Buni fruit (Antidesma burnius). High carbohydrate probably derived from glucose level. It is characterized by a very sweet flavor of the fruit. Sabrang bulbs (Coleus tuberosa) had a higher levels of protein and calcium. It makes Sabrang bulbs (Coleus tuberosa) is best for snack as well as substitute for rice.
\end{abstract}

(C)2015 Universitas Mataram 


\section{PENDAHULUAN}

Pulau lombok merupakan salah satu wilayah di propinsi NTB. Mayoritas penduduknya dihuni oleh masyarakat suku sasak yang merupakan masyarakat asli daerah ini. Di pulau ini terdapat beberapa jenis tumbuhan lokal yang dahulunya sering dimanfaatkan oleh masyarakat sebagai pangan alternatif. Pengetahuan masyarakat tentang tumbuhan pangan tersebut biasanya berasal dari pengalaman hidup, pengetahuan dari turun temurun dan kearifan lokal masyarakat yang perlu mendapat perhatian dari semua pihak.

Hasil inventarisasi terhadap berbagi jenis tumbuhan lokal yang biasa dimanfaatkan oleh masyarakat di pulau Lombok diperoleh 64 jenis tumbuhan lokal yang biasanya dimanfaatkan sebagai pangan alternatif. Bagian buah merupakan bagian tumbuhan yang paling banyak dimanfaatkan sebagai pangan alternatif yaitu sebanyak 27 jenis, biji sebanyak 15 jenis, umbi dan daun sebanyak 10 jenis, sedangkan tumbuhan yang bagian batangnya sering dimanfaatkan sebagai pangan alternatif sebanyak dua jenis (Rohyani et al, 2014). Buahbuhan lokal memiliki bentuk dan cita rasa yang sangat khas sehingga memiliki potensi yang sangat tinggi untuk menggantikan banyaknya buah-buhan impor yang beredar dipasaran saat ini. Bagian biji, daun, umbi dan batang juga memiliki prospek pengembangan untuk memperkuat ketahanan pangan nasional. Ketahanan pangan nasional sangat ditentukan oleh adanya diversifikasi ketersediaan maupun konsumsi pangan oleh masyarakat yang salah satunya dapat bersumber dari tumbuhan pangan lokal. Diversifikasi pangan adalah beragamnya penyediaan suatu bahan pangan sebagai akibat dari proses pemanfaatan dan pengembangan bahan pangan. Pengembangan diversivikasi pangan ini di latar belakang oleh adanya potensi sumber daya hayati yang sangat besar di negara kita. Diversifikasi pangan juga merupakan solusi untuk mengatasi ketergantungan masyarakat Indonesia terhadap satu jenis bahan pangan yakni beras.

Keberadaan tumbuhan pangan lokal saat ini sudah mulai jarang ditemukan. Sekitar $60 \%$ dari jumlah tersebut sudah tidak dibudidayakan (Rohyani et al, 2014). Kondisi ini disebabkan rendahnya nilai ekonomi tumbuhan pangan lokal, karena masyarakat sudah jarang mengkonsumsi atau memanfaatkannya. Cita rasa yang dianggap sudah asing dan tidak sesuai dengan lidah masyarakat saat ini termasuk menjadi salah satu penyebabnya. Di zaman yang serba instan seperti sekarang tumbuhan lokal dianggap kurang praktis dalam pemanfaatnya. Hal lain yang diduga berpengaruh adalah rendahnya pengetahuan masyarakat terhadap nilai gizi dari tumbuhan pangan lokal tersebut. Pemanfaatan tumbuhan lokal sebagai pangan alternatif dalam upaya memperkuat ketahanan pangan nasional tidak terlepas dari pengetahuan terhadap besarnya nilai gizi dari pangan tersebut, sehingga penelitian mengenai kandungan nilai gizi tumbuhan pangan lokal yang paling dikenal dan sering dimanfaatkan oleh masyarakat pulau Lombok perlu dilakukan. Kegiatan ini merupakan salah satu upaya meningkatan peran tumbuhan pangan lokal sebagai substitusi bagi pangan utama yang keberadaanya sudah mulai berkurang. Penelitian ini juga diharapkan dapat menguatkan dan membangkitkan khasanan pangan lokal untuk meningkatkan kesejahteraan masyarakat terutama dalam bidang pangan.

\section{METODOLOGI PENELITIAN}

Dipilih enam jenis tumbuhan pangan lokal sebagai perwakilan untuk di uji kandungan nilai gizinya yang memiliki nilai skor dan bobot tertinggi berdasarkan hasil penelitian (Rohyani, 2014). Tumbuhan tersebut terdiri dari tiga jenis buah-buahan lokal dan tiga jenis umbi-umbian yaitu buah juwet/jamblang (Syzygium cumini), buah kepundung/menteng (Baccaurea racemosa), buah burne/buni (Antidesma burnius), umbi lomak/kimpul (Xanthosoma sagittifolium), umbi sebek/ganyong (Canna edulis), dan umbi sabrang (Caleus tuberosa). Analisis kompenen nilai gizi dilakukan di Laboratorium analitik Universitas Mataram Kandungan nilai gizi tumbuhan lokal dapat diketahui melalui Uji kadar air dengan prosedur pemanasan (AOAC, 1970, Renggana 1979), uji protein dengan prosedur Kjeldhal, uji karbohidrat dengan spectrometri, uji vitamin $\mathrm{C}$ dengan prosedur titrasi Yodium (Jacobs) dan uji $\mathrm{Ca}$ (kalsium) dengan prosedur AAS flame.

\section{HASIL DAN PEMBAHASAN}

Manusia memerlukan makanan yang bergizi terutama untuk energi, proses pertumbuhan, pergantian sel-sel yang rusak dan untuk menjaga kesehatan agar proses-proses 
biokimiawi dalam tubuh tetap berjalan sebagaimana mestinya. Makanan yang bergizi merupakan faktor utama penentu kesehatan manusia. Adapun zat gizi yang diperlukan manusia untuk memenuhi kebutuhan tubuhnya supaya dapat tumbuh dengan baik dan sehat, yaitu karbohidrat, protein, lemak, vitamin, mineral dan air. Berdasarkan kegunaannya zat gizi pada makanan dikelompokkan menjadi tiga kelompok yaitu kelompok zat gizi penghasil energi (karbohidrat dan lemak), kelompok zat gizi pembangun sel (protein) dan kelompok zat gizi pengatur (vitami dan mineral). Pada penelitian tumbuhan pangan lokal ini kandungan zat gizi yang diuji adalah kadar air, protein, karbohidrat, vitamin $\mathrm{C}$ dan kandungan mineral seperti kalsium.

Hasil analisis kandungan nilai gizi beberapa jenis tumbuhan lokal yang biasanya dimanfaatkan oleh masyarakat pulau Lombok sebagai pangan alternatif berdasarkan hasil penelitian (Rohyani, et al., 2014). Disajikan pada Tabel 1.

Tabel 1. Hasil uji kandungan nilai gizi tumbuhan lokal pangan alternatif pulau lombok

\begin{tabular}{|c|c|c|c|c|c|c|}
\hline \multirow[t]{2}{*}{ No } & Jenis Tanaman Pangan & \multicolumn{5}{|c|}{ Hasil uji parameter } \\
\hline & & 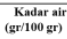 & Protein $(\mathrm{gr} / 100 \mathrm{gr})$ & $\begin{array}{c}\text { Karbohidrat } \\
\text { (gr/100 gr) }\end{array}$ & $\begin{array}{r}\text { Vitamin C } \\
(\mathrm{mg} / 100 \mathrm{gr})\end{array}$ & $\begin{array}{l}\text { Ca (kalsium) } \\
\text { (my/100 gr) }\end{array}$ \\
\hline 1 & $\begin{array}{l}\text { Juwet Jamblang } \\
\end{array}$ & 82.52 & 0.63 & 12.07 & 6.58 & 23.28 \\
\hline 2 & 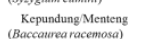 & 80.85 & 0.97 & 6.49 & 2.94 & 53.97 \\
\hline 3 & $\begin{array}{l}\text { Burne buni } \\
\text { (Antidesma burnius) }\end{array}$ & 62.30 & 1.56 & 34.66 & 100.6 & 18.19 \\
\hline 4 & 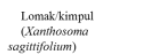 & 68.12 & 1.39 & 1893 & 2.78 & 22.80 \\
\hline$s$ & Sabrang (Caleus tuberssa) & 69.18 & 3.60 & 12.68 & 2.17 & 63.07 \\
\hline 6 & $\begin{array}{l}\text { Schek Ganyong } \\
\text { (Canna dultis) }\end{array}$ & 65.81 & 1.49 & 5.78 & 1.38 & 29.65 \\
\hline
\end{tabular}

Berdasarkan hasil analisis laboratorium diperoleh data bahwa Buah Juwet/Jamblang (Syzygium cumini) memiliki kadar air yang paling tinggi dari keenam jenis tanaman pangan lokal yang diuji, kemudian diikuti oleh buah Kepundung/Menteng (Baccaurea racemosa) dan Sabrang (Caleus tuberosa). Umbi Sebek/Ganyong (Canna edulis) memilik kadar air yang paling rendah. Kadar air secara umum diperlukan untuk kelangsungan proses biokimia organisme hidup. Kadar air dalam bahan pangan berperan sebagai pelarut dan pereaksi dari beberapa komponen. Bentuk kadar air dapat ditemukan sebagai air bebas dan air terikat. Air bebas dapat dengan mudah hilang apabila terjadi penguapan atau pengeringan, sedangkan air terikat sulit dibebaskan dengan cara tersebut. Air dapat terikat secara fisik, yaitu ikatan menurut sistem kapiler dan air terikat secara kimia, antara lain air kristal dan air yang terikat dalam sistem dispersi (Purnomo,1995).

Menurut Sudarmadji (2003) Air yang terdapat dalam bentuk bebas dapat membantu terjadinya proses kerusakan bahan makanan yang disebabkan oleh proses mikrobilogis, kimiawi, ensimatik, bahkan oleh aktivitas serangga perusak. Pernyataan tersebut diperkuat Suprapti (2008) adanya kandungan air dalam jumlah besar akan memberikan peluang hidup dan berkembang biak segala jenis mikroba, termasuk mikroba penyebab kebusukan. Kadar air dalam bahan makanan berhubungan dengan daya simpan bahan makan. Kadar air yang tinggi pada buah Juwet/Jamblang (Syzygium cumini)menyebabkan daya simpan buah ini lebih rendah jika dibandingkan dengan buah Kepundung/Menteng (Baccaurea racemosa) maupun umbi Sabrang (Caleus tuberosa). Menurut Suprapti (2008) buah yang memiliki kadar air di atas 80 memiliki daya simpan 7 sampai dengan 15 hari.

Hasil uji menunjukan bahwa kandungan protein pada umbi Sabrang (Caleus tuberosa) paling tinggi diikuti oleh buah burne/buni (Antidesma burnius) dan umbi sebek/ganyong (Canna edulis). Kandungan protein pada umbi sabrang (Caleus tuberosa) ini lebih tinggi jika dibandingkan dengan kandungan protein pada umbi-umbi lainnya seperi pada umbi kentang, singkong, gadung, ubi rambat dan uwi yang kandungan proteinnya rata-rata di bawah 2 gram/100 gram. Namun kandungan nilai gizi protein ini masih jauh lebih rendah jika dibandingkan dengan kandungan gizi tanaman pangan yang biasa dikonsumsi masyarakat seperti beras putih $(6,8$ gr) dan jagung putih (9,2 gr) (Poedjiadi, 1994).

Protein merupakan kelompok makronutrisi berupa senyawa asam amino yang berfungsi sebagai zat pembangun dan pendorong metabolisme dalam tubuh. Zat ini tidak dapat dihasilkan sendiri oleh manusia kecuali lewat makanan yang mengandung protein. Protein dalam mahluk hidup berperan dalam sistem kekebalan (imun) sebagai antibodi, sistem kendali dalam bentuk hormon, sebagai komponen penyimpanan (dalam biji) dan juga dalam transportasi hara. Protein juga berperan dalam menjaga keseimbangan $\mathrm{pH}$ asam dan basa tubuh. Berperan juga sebagai cadangan makanan dan energi dalam tubuh mahluk hidup. Pada 
tumbuhan terbentuknya protein bermula dari proses anabolisme dan kemudian dirombak pada tumbuhan tersebut melalui proses katabolisme. Adanya protein pada tumbuhan dapat dilihat dari adanya kandungan nitrogen pada tumbuhan. nitrogen merupakan unsur yang dominan mempengaruhi pertumbuhan tanaman. Pembentukan protein pada tanaman memerlukan adanya nitrogen dan apabila kekurangan nitrogen dapat diartikan sebagai kekurangan protein.

Buah Burne/ Buni (Antidesma burnius) memiliki nilai kandungan karbohidrat yang tinggi, diikuti oleh umbi lomak/kimpul (Xanthosoma sagittifolium) dan umbi sabrang (Caleus tuberosa), sedangkan umbi sebek/ganyong (Canna edulis),) memiliki kandungan karbohidrat yang paling rendah. Di dalam tumbuhan karbohidrat mempunyai dua fungsi utama, ialah sebagai simpanan energi dan sebagai penguat struktur tumbuhan tersebut. Karbohidrat yang terdapat di dalam makanan pada umumnya hanya tiga jenis, ialah monosakarida, disakarida dan polisakarida. Rasa manis pada buah Burne/ Buni (Antidesma burnius) diduga menyebabkan kandungan karbohidrat pada buah ini sangat tinggi. Karbohidrat pada buah Burne/ Buni (Antidesma burnius) berasal dari karbohidrat jenis Mono dan disakarida terasa manis. Karbohidrat yang terdapat pada umbi lomak/kimpul (Xanthosoma sagittifolium) dan umbi sabrang (Caleus tuberosa) diduga berasal dari kelompok karbohidrat polisakarida yang tidak mempunyai rasa (tawar). Di dalam bahan makanan nabati terdapat dua jenis polisakarida yang dapat dicerna yaitu zat tepung (amylum) dan dekstrin. Timbunan zat tepung terdapat dalam biji, akar dan batang. Gula terdapat di dalam daging buah atau di dalam cairan tumbuhan di dalam batang (tebu) (Sediaoetama, 2004).

Hasil uji nilai kandungan vitamin $\mathrm{C}$ pada buah Burne/ Buni (Antidesma burnius) sangat tinggi dibanding dengan lima tanaman pangan yang diuji lainnya, kandungan vitamin $\mathrm{C}$ ditemukan tinggi juga pada buah juwet/jamblang (Syzygium cumini) dan buah kepundung/menteng (Baccaurea racemosa). Kandungan vitamin $\mathrm{C}$ yang terrendah ada pada umbi sabrang (Caleus tuberosa). Vitamin C diproduksi oleh tumbuhan dalam jumlah yang besar. Fungsi vitamin $\mathrm{C}$ bagi tumbuhan adalah sebagai agen antioksidan yang dapat menetralkan singlet oksigen yang sangat reaktif, berperan dalam pertumbuhan sel, berfungsi seperti hormon, dan ikut berperan dalam proses fotosintesis (Davey, 2006). Menurut Smirnoff (1996) vitamin C juga berperan untuk melindungi tumbuhan dari kerusakan oksidatif yang dihasilkan dalam proses metabolisme aerobik, fotosintesis, dan polutan. Vitamin C hanya dapat dibentuk oleh tumbuhan dan terdapat pada sayuran serta buah-buahan dalam jumlah yang besar. Hal ini disebabkan karena tumbuhan memiliki enzim mikrosomal Lgulonolakton oksidase, sebagai komponen dalam pembentukan asam askorbat (Nasoetion \& Karyadi, 1987 dan Padayatty et al., 2003).

Tingginya kandungan Vitamin $\mathrm{C}$ pada buah Burne/ Buni (Antidesma burnius) diduga terkait dengan tingginya kandungan karbohidrat (glukosa dan galaktosa) yang dapat dimanfaatkan sebagai prekursor untuk pembentukan vitamin C. Hasil uji vitamin C pada buah Burne/ Buni (Antidesma burnius) $100,61 \mathrm{mg} / 100 \mathrm{~g}$ lebih tinggi bila dibandingkan dengan kandungan vitamin $\mathrm{C}$ yang terdapat pada buah mangga, melon, rasberry, dan limau yaitu $\pm 20 \mathrm{mg} / 100 \mathrm{~g}$, lemon $\pm 40 \mathrm{mg} / 100 \mathrm{~g}$, sedangkan jeruk dan strawberi, yaitu \pm 50 $\mathrm{mg} / 100 \mathrm{~g}$ (Combs, 2008). Kandungan vitamin C yang tinggi pada buah Burne/ Buni (Antidesma burnius) memiliki potensi sebagai sumber antioksidan dan suplemen kesehatan.

Umbi sabrang (Caleus tuberosa) memiliki kandungan kalsium yang tinggi diikuti oleh buah kepundung/menteng (Baccaurea racemosa) dan umbi sebek/ganyong (Canna edulis). Buah burne/buni (Antidesma burnius) memiliki nilai kalsium yang rendah dibanding dengan jenis pangan lokal yang diuji lainnya (Tabel 1). Kandungan kalsium pada umbi sabrang (Caleus tuberosa) lebih tinggi dibandingkan kandungan kalsium pada lobak (35 gr/100 gr), Wortel (39 gr/100 gr), terong (15 $\mathrm{gr} / 100 \mathrm{gr})$, tomat $(5 \mathrm{gr} / 100 \mathrm{gr})$ dan buah jeruk (33 gr/100 gr) (Poedjiadi, 1994). Kalsium merupakan mineral yang amat penting bagi manusia, terutama untuk meningkatkan metabolisme tubuh, penghubung antar saraf, kerja jantung, dan pergerakan otot. Keberadaan kalsium sangat diperlukan tanaman terutama dalam pembentukan protein. Tingginya kandungan kalsium pada umbi sabrang (Caleus tuberosa) diduga turut dipengaruhi oleh tingginya kandungan protein pada umbi sabrang 
(Caleus tuberosa). Namun kondisi ini tidak berlaku untuk buah burne/buni (Antidesma burnius) yang juga memiliki kandungan protein yang tinggi namun memiliki kandungan kalsiumn paling rendah diantara lima jenis tanaman lokal lainnya yang diujikan. Kalsium merupakan bagian esensial dari struktur dinding sel tanaman, menyediakan pengangkutan dan retensi unsur-unsur lain di dalam tanaman. Kalsium juga diketahui sebagai unsur yang dapat melawan garam alkali dan asam organik pada tanaman. kalsium dimanfaaatkan oleh tanaman untuk mengaktifkan pembentukan bulu-bulu akar dan biji serta menguatkan batang. Membantu keberhasilan penyerbukan. Membantu pemecahan sel. Membantu aktivitas beberapa enzim pertumbuhan, serta menetralisir senyawa dan kondisi tanah yang merugikan. Kalsium (ca) merupakan salah satu unsur hara makro sekunder yang memiliki peran cukup penting dalam siklus hidup tanaman. Unsur hara ini menjadi komponen utama penyusun struktur dinding sel dan membran tanaman. Kalsium (ca) dibutuhkan dalam jangka pendek untuk meminimalisir terjadinya infeksi dari organisme penyebab penyakit yang bersinggungan dengan bagian luar tanaman.

\section{KESIMPULAN}

Buah Juwet/Jamblang (Syzygium cumini) merupakan salah satu buah-buahan lokal yang memiliki kadar air yang tinggi sehingga menyebabkan daya simpan buah ini lebih rendah jika dibandingkan dengan buah lokal lainnya. Umbi Sabrang (Caleus tuberosa) memiliki kandungan protein dan kalsium $(\mathrm{Ca})$ yang paling tinggi sehingga sangat potensial untuk dikembangkan sebagai alternatif pangan lokal yang bergizi. Kandungan karbohidrat dan Vitamin C buah Burne/buni (Antidesma burnius) paling tinggi diantara tumbuhan lokal lainnya sehingga memiliki potensi untuk dikembangkan sebagai sumber antioksidan dan suplemen kesehatan.

\section{DAFTAR PUSTAKA}

AOAC. 1970. Official method and analysis of the association oh the official analytical chemists. 11th. Edition. Washington D.C.

Combs GF. 2008. The vitamins, fundamental aspects in nutrition and health. 2nd ed.
San Diego, CA: Academic Press, 2001 : 245-272.

http://en.wikibooks.org/wiki/Nutrition/V itamin_C. 8 Februari 2009.

Davey GCL. 2006. A mood-as-input acccount of perseverative worrying. In.G.C.L.

Davey \& A. Wells (Eds). Worry and its psychological disorders: Theory assessment and treatment (PP.207-238) Chichester England: Willey.Nasoetion \& Karyadi, 1987

Padayatty SJ, Katz A, Wang Y, Eck P, Kwon O, Lee JH, Chen S, Corpe C, Dutta A, Dutta SK, Levine M. 2003. Vitamin $\mathrm{C}$ as an antioxidant: evaluation of its role in disease prevention. Pulmed. Gov.

Poedjiadi A. 1994. Dasar-dasar biokimia. UIPress, Jakarta.

Purnomo H. 1995. Aktifitas air dan peranannya dalam pengawetan pangan. UI-Press, Jakarta.

Renggana S. 1979. Manual of analisis of fruit and vegetable product. Mc graw hill, New Delhi.

Rohyani IS, Aryanti E, Suripto. 2014. Potensi tumbuhan lokal pulau lombok dalam upaya menunjang ketahanan

Pangan. Proceeding Seminar Nasional Pendidikan Matematika, Sains dan TIK STKIP Surya. Jakarta.

Sediaoetama AD. 2004. Ilmu gizi. Dian Rakyat. Jakarta.

Smirnoff N, Pallanca JE. 1996. The control of ascorbic acid synthesis and turnover in pea seedlings. Oxford Journals. Science \& Mathematics. Journal of Experimental Botany.Volume 51, Issue 345. Pp. 669-674.

Sudarmadji, Slamet H. Bambang, Suhardi. 2003. Analisa bahan makanan danpertanian. Liberty. Yogyakarta.

Suprapti ML. 2008. Membuat saos tomat. Trubus Agrisarana, Jakarta. 